

\section{DISCLAIMER}

This report was prepared as an account of work sponsored by an agency of the United States Government. Neither the United States Government nor any agency Thereof, nor any of their employees, makes any warranty, express or implied, or assumes any legal liability or responsibility for the accuracy, completeness, or usefulness of any information, apparatus, product, or process disclosed, or represents that its use would not infringe privately owned rights. Reference herein to any specific commercial product, process, or service by trade name, trademark, manufacturer, or otherwise does not necessarily constitute or imply its endorsement, recommendation, or favoring by the United States Government or any agency thereof. The views and opinions of authors expressed herein do not necessarily state or reflect those of the United States Government or any agency thereof. 


\section{DISCLAIMER}

Portions of this document may be illegible in electronic image products. Images are produced from the best available original document. 


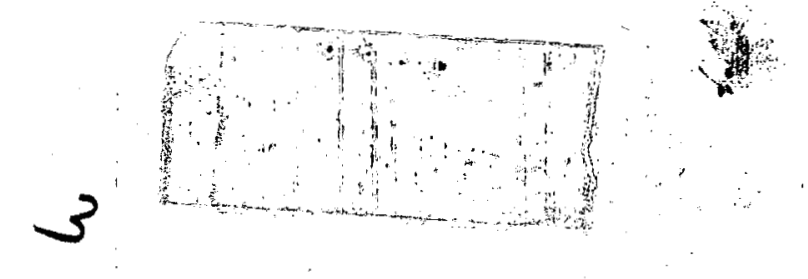

\title{
PRELIMINARY REPORT ON LOW COLUMBIUM: URANIUM CORROSION RESISTANT ALLOYS
}

by

J. E. Draley

\begin{abstract}
ABSTRAC T
Uranium alloys containing 3 and $6 \mathrm{w} / \mathrm{o}$ niobium have been prepared in which the impurity content is rather low. These alloys show very promising resistance to corrosion by water at 260 and $300^{\circ} \mathrm{C}$. The corrosion resistance is exhibited in degassed water and in water which is saturated with air or oxygen at room temperature before testing.
\end{abstract}

It is possible that even the alloy containing $3 \mathrm{w} / \mathrm{o}$ niobium will have corrosion resistance to water sufficient to make feasible the design and construction of high temperature water-cooled reactors, using this material as core. Investigations are under way to determine whether this protection from corrosion by the addition of niobium will be permanent or of long enough duration to make the material usable in the application mentioned.

Other alloys are being prepared in the investigation seeking corrosion resistant alloys, most of them containing niobium in amounts less than $3 \%$. The next group of alloys will contain zirconium in addition to niobium, in an effort to provide satisfactorily corrosion resistant alloys in which the niobium content is not undesirable from neutron capture standpoint.

Introduction

There has been and continues to be demand for a uranium-rich corrosion resistant alloy. Especially for high temperature water-cooled reactors it is desirable to have an alloy that will not cause considerable operational difficulty in the event of a failure of the cladding used over the uranium fuel to prevent fission loss to the coolant.

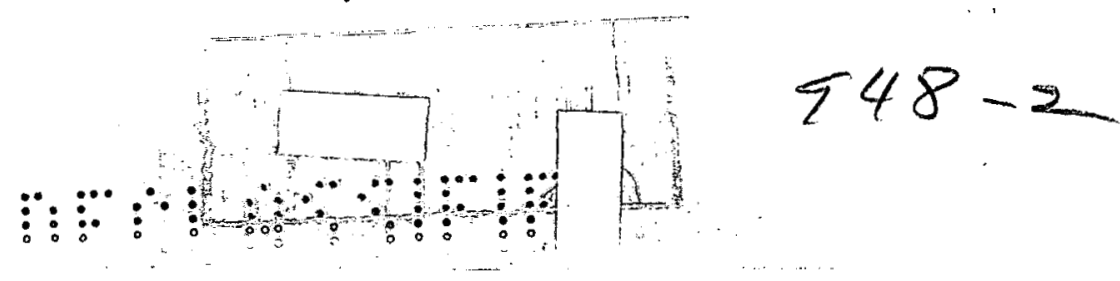




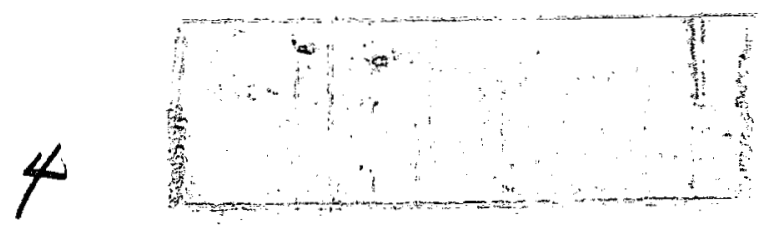

In a recent report the corrosion behavior or uranium alloys containing small amounts of zirconium was described.

A study of older corrosion data as summarized in ANL-4862, ${ }^{2}$ and consideration of the behavior of zirconium alloys has led to a program of preparation of alloys containing niobium and zirconium and an evaluation of their corrosion resistance in high temperature water. It has been known that alloys containing as much as $6 \mathrm{w} / 0 \mathrm{Nb}$ are highly resistant to aqueous corrosion at temperatures at least as high as $180^{\circ} \mathrm{C}$. Recently ${ }^{3}$ cast and heat-treated samples of this alloy showed promising corrosion resistance as high as $3000^{\circ} \mathrm{C}$. The procedure planned for the preparation of suitable corrosion-resistant alloys is first to learn the minimum amount of niobium required to give adequate corrosion resistance. Next, smaller amounts of this alloying constituent will be tried, with additions of zirconium to provide better corrosion resistance. If deemed desirable, small additions of molybdenum and/or nickel will also be made to alloys.

Experimental

Three alloys were prepared for initial studies. These were intended to contain respectively $6 \%$ niobium, 3\% niobium, and $1.5 \%$ niobium and $1.5 \%$ zirconium. The first casting of the $3 \% \mathrm{Nb}$ alloy (H183) was unsound, so a second casting was made (H187).

All of the alloys were induction melted, cast in magnesia crucibles, and rolled to $50 \%$ reduction. Rolling temperature for the first two alloys was $850^{\circ} \mathrm{C}$; for the ternary containing small amounts of niobium and zirconium it was $650^{\circ} \mathrm{C}$. Preparation and fabrication of the alloys was done by the Foundry and Fabrication group of the Metallurgy Division. Chemical and spectrographic analyses of the alloys prepared are given in Table I. Analyses of samples as reported are for the section of the rods from which corrosion specimens were cut. There were relatively small differences in concentrations for different parts of the rods. The accuracy of the nitrogen analyses is suspect.

Sample materials were held at a temperature intended to be $800^{\circ} \mathrm{C}$ for one hour in vacuo and water quenched. Because of a faulty thermocouple, the actual temperature was higher - believed to be about $1100^{\circ} \mathrm{C}$. They were then ground to a. smooth finish both on peripheral surface and ends, giving samples approximately $9 / 16$ inch diameter and $1 / 2$ inch long.

${ }^{1}$ ANL-5030 - The Corrosion of Low Zirconium: Uranium Alloys in Boiling Water, J.E. Draley, J.W. McWhirter, F. Field, J. Guon April 14, 1953.

${ }^{2}$ ANL-4862 - Aqueous Corrosion of Uranium and Alloys: Survey of Project Literature, J. W. Mc Whirter and J. E. Draley - May 14, 1952.

${ }^{3}$ ANL-5036 - Progress Report for January - March, 1953. 
Table I

ANALYSIS OF ALLOYS AS TESTED

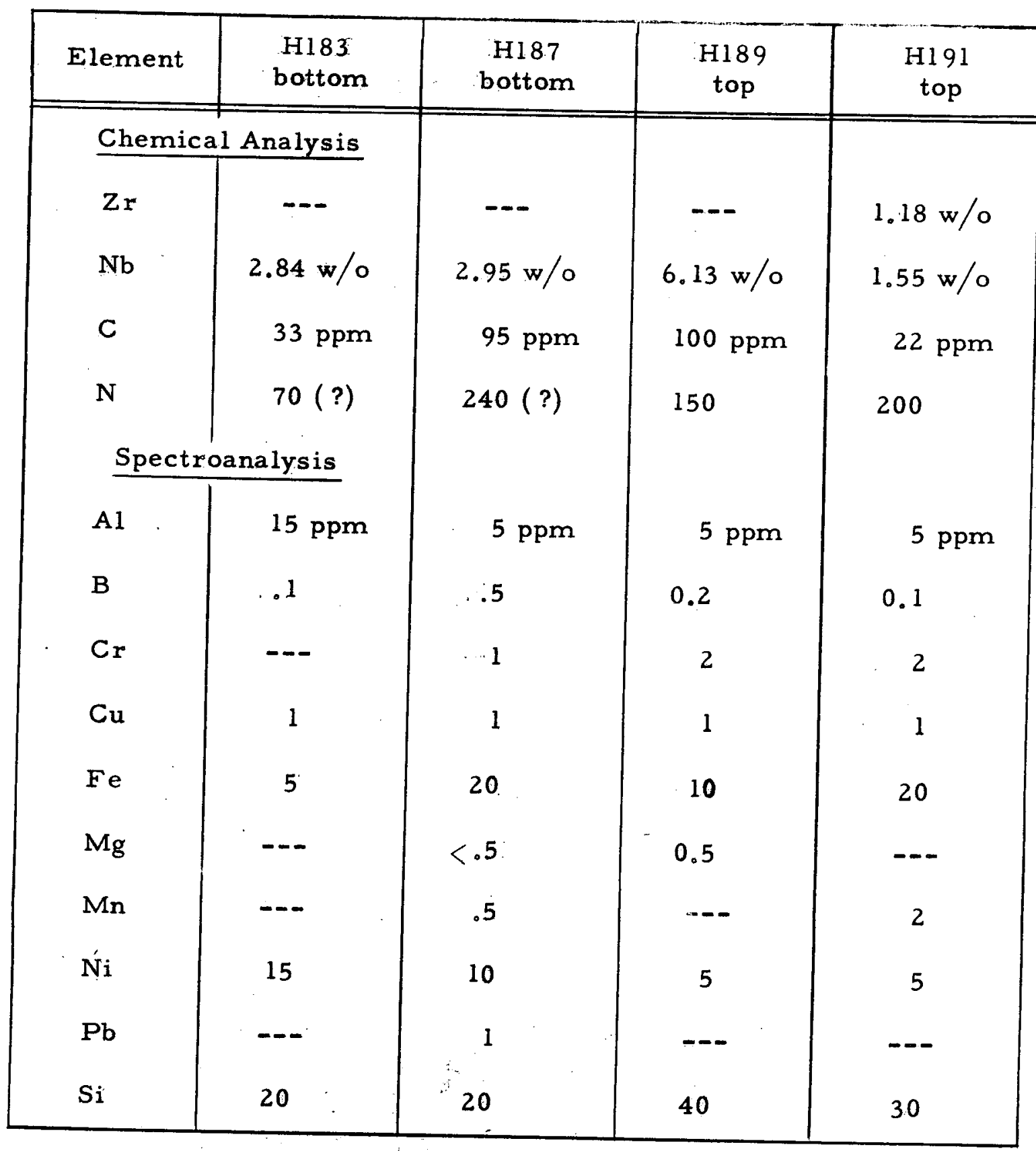

Several of these samples were wet ground on a metallographic polishing wheel, finishing with 400 grit abrasive paper, and degreased, weighed, and placed on test in stainless steel autoclaves. The samples were supported on racks made of synthetic'sapphire rods to insulate them from contact with the autoclaves. Samples were tested in redistilled water for slightly less than three days. Results of the setests are given in Table II. The niobium alloys were darkened in color with the nominal $3 \%$ essentially black, as shown in Figure 1. No attempt was made to remove the adherent 
6

protective oxide film which existed on the metal surfaces after test. The niobium-zirconium ternary alloy had disintegrated during the tests. For the $\%$ niobium alloy samples the amount of corrosion was perhaps slightly less for the water containing air than for degassed water.

Table II

CORROSION OF ALLOYS IN WATER AT $300^{\circ} \pm 4^{\circ} \mathrm{C}$

\begin{tabular}{|c|c|c|c|c|}
\hline Alloy & $\begin{array}{l}\text { Hours } \\
\text { in } \\
\text { Test }\end{array}$ & $\begin{array}{c}\text { Test } \\
\text { Condition }\end{array}$ & $\begin{array}{l}\text { Rate of } \\
\text { Weight Loss } \\
\mathrm{mg} / \mathrm{cm}^{2} / \mathrm{hr}\end{array}$ & Comment \\
\hline $183(3 \% \mathrm{Nb})$ & 64 & $\begin{array}{l}\text { degassed }^{1} \\
\text { air sat. }\end{array}$ & $\begin{array}{l}1.3 \\
0.7\end{array}$ & $\begin{array}{l}\text { Attacked at rolled-in } \\
\text { seam. Metal chipped. } \\
\text { In contact with auto- } \\
\text { clave wall. }\end{array}$ \\
\hline \multirow[t]{2}{*}{$187(3 \% \mathrm{Nb})$} & 64 & degassed $^{1}$ & 0.7 & $\begin{array}{l}\text { Lost some water, sample } \\
\text { above water line. }\end{array}$ \\
\hline & 70 & air sat. 2 & 0.6 & \\
\hline \multirow[t]{2}{*}{$189(6 \% \mathrm{Nb})$} & 64 & degassed $^{1}$ & 0.05 & $\therefore$ \\
\hline & 70 & air.sat. ${ }^{2}$ & & $\begin{array}{l}\text { Sample badly pitted, } \\
\text { noted to be porous } \\
\text { before test. }\end{array}$ \\
\hline $191(1.5 \% \mathrm{Nb}$, & 64 & degassed & & Disintegrated \\
\hline $1.2 \% \mathrm{Zr})$ & 70 & air sat. 2 & & Disintegrated \\
\hline
\end{tabular}

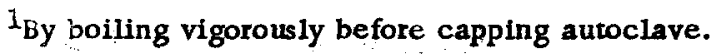

${ }^{2}$ Saturated at room temperature; the water then sealed in autoclave with approximately an equal volume of air before heating.

Another series of tests was run in the Reactor Engineering Division, using samples of the same batch, after heat-treatment. In this case samples were used as received from the shop except for degreasing. They were placed in stainless steel autoclaves without insulation from the steel. The temperature was $260^{\circ} \mathrm{C}\left(500^{\circ} \mathrm{F}\right)$. Degassed distilled water and water saturated with oxygen at room temperature were used. Results are summarized in Table III.

For these tests, apparent corrosion rates for the short exposure perlods were indicated to be somewhat greater in the oxygen-saturated water than in the degassed water. It is of interest to note that for completed 

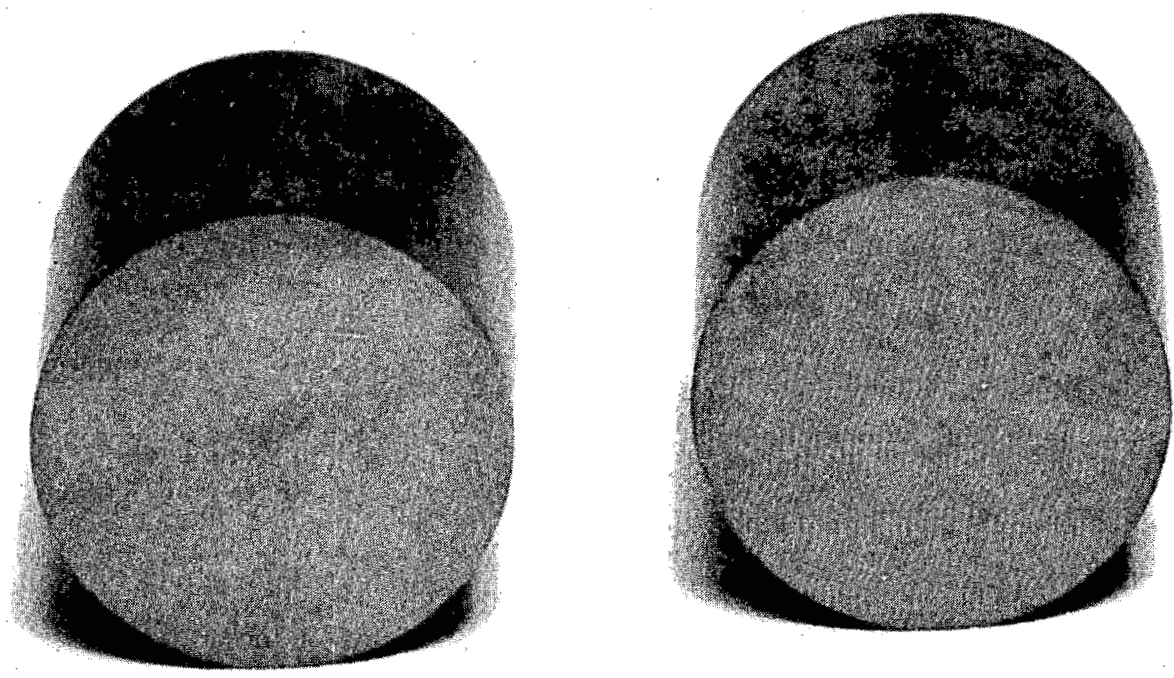

14,347

H 183

म 187

$3 \cdot 3 x$

Figure 1

3\% NIOBIOM AIIOY AFTER TEST IN WATER AT $300^{\circ} \mathrm{C}$ 
Table III

CORROSION OF ALLOYS IN WATER AT $260^{\circ} \mathrm{C}\left(500^{\circ} \mathrm{C}\right)$

\begin{tabular}{|c|c|c|c|}
\hline Alloy & $\begin{array}{c}\text { Hours in } \\
\text { Test }\end{array}$ & $\begin{array}{c}\text { Test } \\
\text { Condition }\end{array}$ & $\begin{array}{c}\text { Rate of Weight Change } \\
\mathrm{mg} / \mathrm{cm}^{2} / \mathrm{hr}\end{array}$ \\
\hline $183(3 \% \mathrm{Nb})$ & $\begin{array}{r}19 \\
185 \\
24\end{array}$ & $\begin{array}{l}\text { Degassed } \\
\text { Degassed } \\
\text { Oxygen Sat. }\end{array}$ & $\begin{array}{l}-0.40 \\
-\quad .32 \\
-1.24\end{array}$ \\
\hline $187(3 \% \mathrm{Nb})$ & $\begin{array}{r}19 \\
185 \\
24\end{array}$ & $\begin{array}{l}\text { Degassed } \\
\text { Degassed } \\
\text { Oxygen Sat. }\end{array}$ & $\begin{array}{l}-.33 \\
-\quad .18 \\
-\quad .64\end{array}$ \\
\hline $189(6 \% \mathrm{Nb})$ & $\begin{array}{r}19 \\
185 \\
24\end{array}$ & $\begin{array}{l}\text { Degassed } \\
\text { Degassed } \\
\text { Oxygen Sat. }\end{array}$ & $\begin{array}{r}+.015 \\
-\quad .064 \\
+\quad .025\end{array}$ \\
\hline $\begin{array}{c}191(1.5 \% \mathrm{Nb} \\
1.2 \% \mathrm{Zr})\end{array}$ & $\begin{array}{l}19 \\
24\end{array}$ & $\begin{array}{l}\text { Degassed } \\
\text { Oxygen Sat. }\end{array}$ & $\begin{array}{l}\text { Disintegrated } \\
\text { Partially } \\
\text { disintegrated }\end{array}$ \\
\hline
\end{tabular}

tests of longer duration, average rates of weight change were lower for the $3 \%$ niobium alloy than the 1 day tests. It is inferred that corrosion rates were more rapid at the beginning of the exposure than at subsequent times. Sample appearances were much the same as for those tested at the higher temperature reported in Table II, except that the $6 \%$ niobium alloy showed the formation of a yellow corrosion product in the oxygenated water. The appearance of the yellow product suggests that it is a higher oxide of uranium.

Metallographic examination of the $3 \%$ niobium alloy was made. As cast the structure was multi-phased and showed generally no easily discernible grain structure. Presumably the metal was in the alpha condition and contained rather large amounts of precipitated niobium and/or niobium containing phase. After heat-treatment and corrosion testing the structure had the appearance shown in Figure 2 where large grains clearly defined are evident. The fine precipitate which is scattered throughout the metal has not been identified, although it is presumed that it contains niobium. This type of structure is quite unusual for quenched alpha uranium, but a reflection X-ray spectrogram (Métallurgy No. 91) and a diffraction pattern on filings (No. 39.54) showed the existence of only alpha uranium. The lines were rather diffuse, probably indicating distortion of the lattice. A powder diffraction pattern of the oxide scraped from the sample showed only diffuse lines of $\mathrm{UO}_{2}$, with lattice dimensions slightly smaller than normal (No. 3955). 


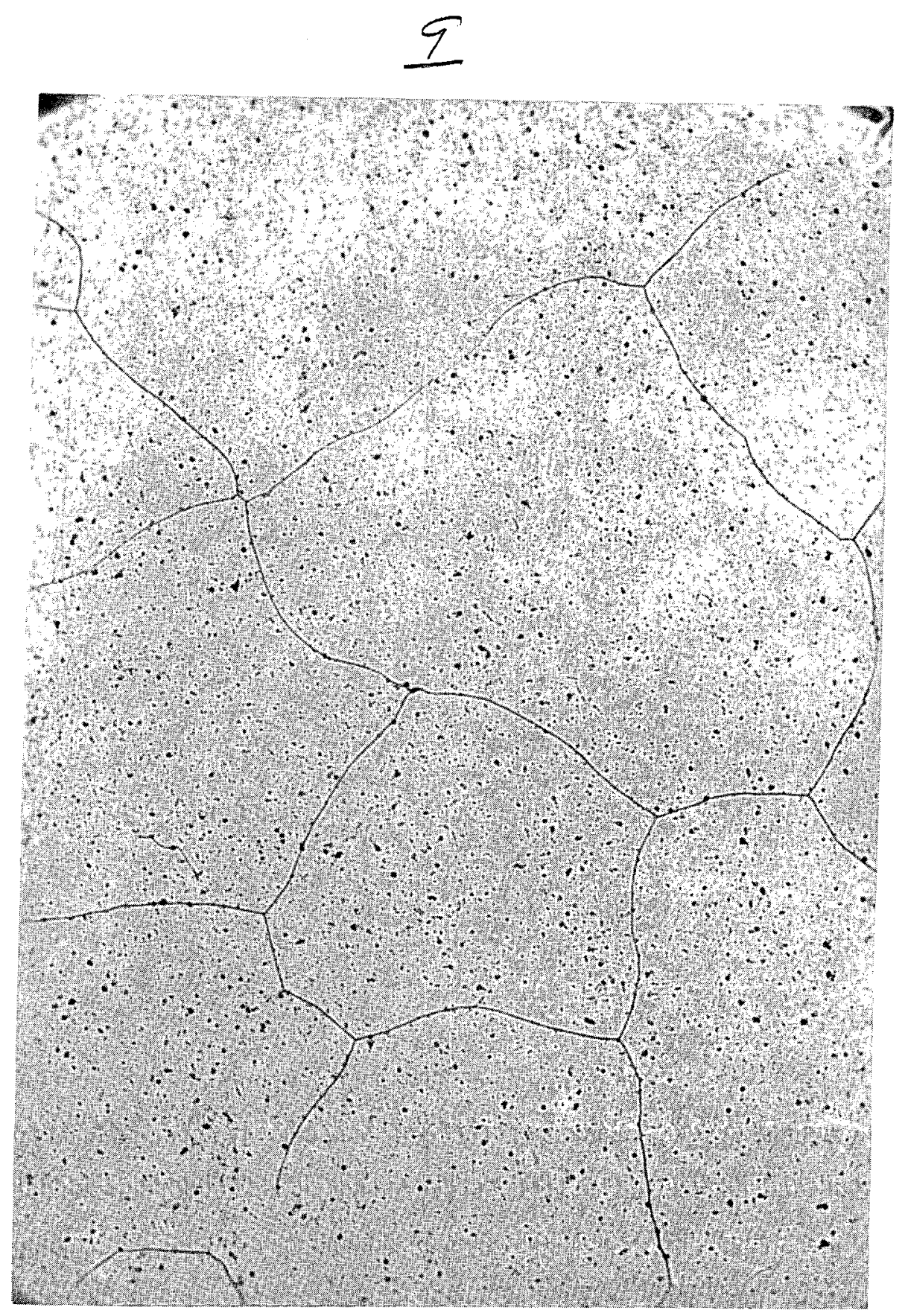

14,349

Electropolished, Bright Field

$100 x$

Figure 2

STRUCTURE OF 3\% NO ALIOY (Hב 87) HEAT TREATED

AND CORROSION TESTED 70 HOURS AT $300^{\circ} \mathrm{C}$ 
Results and Recommendations

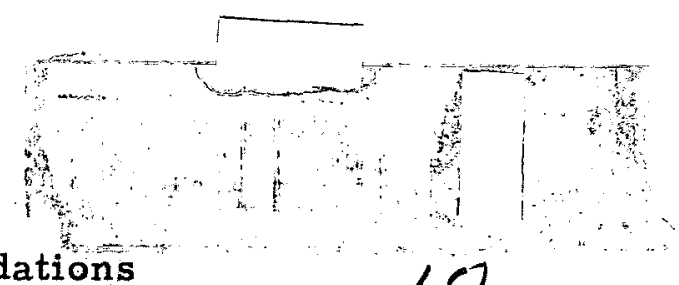

Data reported herewith are the result of what must be described as preliminary investigations into the development of corrosion resistant alloys. They are reported this early in the program because of the success experienced in producing an alloy, namely, that containing $3 \%$ niobium, which might be sufficiently corrosion resistant to make feasible high temperature, watercooled, natural uranium reactors, whose fuel elements will not result in dangerous reaction upon accidental exposure to the coolant. Its neutron absorption probably should be described as higher than desirable, but tolerable.

It has not yet been ascertained whether the short time tests performed are overly optimistic concerning the ability of the $3 \%$ niobium alloy to withstand the corrosive effect of water at high temperatures for long periods. Apparently the metal in the quenched condition exists as alpha uranium, probably with some of the niobium present in the form of a super-saturated solution and some also in the fine, randomly-distributed precipitate. Whether this material is susceptible to aging effects is not known. It is quite possible and perhaps likely that with long time aging at moderately elevated temperatures whatever niobium exists in super-saturated solution will precipitate. Since the amount of niobium in solution in this fashion is not known, it cannot be predicted with confidence what will happen to the corrosion resistance of the metal.

To check the effect, samples of this heat-treated alloy are being held at moderately elevated temperatures for periods of time and re-examined for changes in structure and corrosion resistance. At the same time corrosion tests of long duration have been started by the Reactor Engineering Division.

Work is continuing in the preparation of more alloys in the series. Most of these alloys contain smaller amounts of niobium than the $3 \%$ shown to be of interest. Several have amounts of zirconium up to $10 \mathrm{w} / \mathrm{o}$ in addition, in an attempt to provide the stabilization required to form protective films on uranium alloys when exposed to high temperature water.

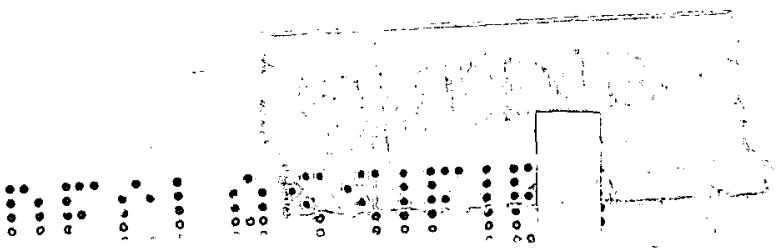

